\title{
Integrating Intercultural Communicative Competence into Teacher Education for Young Learners
}

Kültürlerarası İletişim Yetkinliğinin Çocuklar için

Öğretmen Eğitimine Dahil Edilmesi

\author{
Deniz Şallı-Çopur \\ Middle East Technical University, Turkey
}

\begin{abstract}
Interaction, communication, and cooperation among different cultures are no longer optional skills but must competencies for professional contexts all around the globe in the 21st century. As English is the medium of professional encounters in today's world, foreign language teaching is responsible for developing these competencies from the early years of education. This results in culture being an important component of foreign language classes, which puts a heavy responsibility on teachers' shoulders. Although they may show a sincere effort to integrate culture into lessons, their attempt mostly stays at a basic level focusing on superficial information shared in the language teaching coursebooks published by the global or local publishers. Thus, integrating culture and intercultural communicative competence (ICC) into foreign language teaching needs to be addressed in pre-service teacher education. This paper reports an action research study where a teacher educator investigates her own practice in integrating ICC into a pre-service teacher education session on teaching English to young learners. Thus, the study aims to explain how effective a training session can be in achieving its ICC goals and discover what teacher candidates think about integrating culture and ICC into foreign language teaching based on their training session experience.
\end{abstract}

Keywords: Pre-service Teacher Education, Teaching English to Young Learners, Intercultural Communicative Competence, Action Research

Öz

Farklı kültürler arasında etkileşim, iletişim ve iş birliği 21. yüzyılda profesyonel bağlamlar için artık zorunlu yeterliliklerdir. İngilizce, günümüz dünyasında mesleki karşılaşmaların ortamı olduğu için, yabancı dil öğretimi, eğitimin ilk yıllarından itibaren bu yeterliliklerin geliștirilmesinden sorumludur. Bu da kültürün yabancı dil derslerinin önemli bir bileşeni olmasına neden olmakta ve öğretmenlerin omuzlarına ağır bir sorumluluk yüklemektedir. Öğretmenler, derslerine kültürü dahil etmek için samimi bir çaba gösterseler de girişimleri çoğunlukla küresel veya yerel yayıncılar tarafından hazırlanan dil öğretimi ders kitaplarında paylaşlan yüzeysel bilgilere dayanmaktadır. Bu nedenle, hizmet öncesi öğretmen eğitimine kültür ve kültürlerarası iletişim yeterliliğinin dahil edilmesi önemlidir. Bu makale, bir öğretmen eğitimcisinin bu yeterliliği çocuklara İngilizce öğretmeye yönelik bir hizmet öncesi öğretmen eğitimi oturumuna entegre ettiği uygulamasının araştırıldığı bir eylem araştırması üzerinedir. Çalışma, kültürlerarası iletişim yeterliliği hedeflerine ulaşmada bir eğitim oturumunun ne kadar etkili olabileceğini açıklamayı ve öğretmen adaylarının bu eğitim oturumu deneyimlerine dayanarak kültür ve kültürlerarası iletişim yeterliliğini yabancı dil öğretimine dahil etme konusundaki düşündüklerini keşfetmeyi amaçlamaktadır. 
Anahtar Kelimeler: Hizmet Öncesi Öğretmen Eğitimi, Çocuklara İngilizce Öğretimi, Kültürlerarası İletişim Yeterliliği, Eylem Araştırması

\section{Introduction}

The United Nations Educational, Scientific and Cultural Organization (UNESCO) was founded on November 16, 1945, right after the Second World War, to build and protect world peace through cooperation among nations in education, science, and culture. The official website of the organization titled "UNESCO in brief- Mission and Mandate" greets its visitors with a statement taken from the UNESCO constitution: "Since wars begin in the minds of men and women, it is in the minds of men and women that the defences of peace must be constructed". The Republic of Turkey was one of the countries which signed this constitution in the 1945 convent. As a member of the Turkish delegation, Hasan Âli Yücel, the minister of Turkish National education during World War II, addressed the delegates from more than 40 countries and shared the three guiding principles of Turkish national education (UNESCO Preparatory Commission 54):

(a) To know, understand and form a true estimate of all the nations of the world.

(b) To draw on the common sources of human civilisation, without remaining within the narrow framework of chauvinistic culture.

(c) To refrain from any distinction between citizens, in regard to race, sex, language, religion or class.

These principles were expressed more than 75 years ago by the Turkish delegation, but they are still valid in educating future generations and establishing healthy relations, interactions, and communications among local cultures of a country or world nations. Languages are the medium of interaction and communication between/among people from different cultural and national backgrounds. Healthy communication depends not only on being proficient in a language in terms of its four skills but also on mutual understanding and respect. As today's world requires people to interact with others living and working all around the globe from metropolitans to small villages, from developed to underdeveloped countries, foreign language teaching should also address intercultural communications.

Undeniably, English is a widely used international language both between its native and non-native speakers and among a high number of non-native speakers from different parts of the world. Therefore, "incorporating ICC teaching into English language teaching is crucial to create a classroom environment that goes beyond different cultures of different individuals with different backgrounds" (Güneş and Mede 355). In this sense, including intercultural communicative competence into foreign language teacher education is highly essential because effective training of language teachers on ICC leads to the successful education of young learners (YLs), which is likely to have a constructive impact on the whole society. Hence, the point of departure in this action research is that foreign language teachers should be equipped with 
the awareness, knowledge, and skills to develop ICC in their students and that foreign language teacher education programs should integrate teaching and developing this competence into their methodology classes to prepare teacher candidates.

\section{Literature Review}

Competence has always been an important concept in foreign language education since it was first introduced and had an impact on foreign language teaching methodology, materials design, and testing. Chomsky (4) makes "a fundamental distinction between competence (the speaker/hearer's knowledge of his language) and performance (the actual use of language in concrete situations)" considering children acquiring a first language. According to that, linguistic competence is the knowledge a native speaker has of his/her native language and the ability to distinguish grammatical and ungrammatical utterances. From this perspective, the goal for foreign language learners is to identify and produce grammatical sentences to show their linguistic competence in a foreign language, and teacher education aims to equip teacher candidates with the skills and techniques to help language learners to do so.

Chomsky's idea of linguistic competence was criticized for being narrow to explain different uses of language and ignoring pragmatic language use, which gave rise to a more comprehensive concept: communicative competence. Hymes took competence from a sociocultural perspective showing the relation between language use and social aspects. Thus, children born into different speech communities may show different levels of competence depending on their acquisition of not only grammar but also appropriate language use. According to Hymes, a speaker should fulfil four aspects in his/her utterances to be considered communicatively competent. These aspects are possibility, feasibility, appropriateness, and occurrence ("On Communicative Competence" 284-286). The first of these aspects, possibility, is about whether an utterance is grammatically acceptable or possible within a formal system. The second aspect, feasibility, depends on "psycholinguistic factors such as memory limitation" ("On Communicative Competence" 285). Although an utterance is possible within a formal system, it may not be feasible to produce due to psycholinguistic factors. Appropriateness is the third aspect of communicative competence and entails tacit knowledge about cultural or contextual factors. An utterance appropriate in one context may be inappropriate in another due to changes such as formality. The fourth and the last aspect is about the probabilities of occurrences: "whether something is done". Language users are consciously or unconsciously aware of the structural changes that can be done within the boundaries of possibility, feasibility, and appropriateness. To illustrate, the utterance 'we used to watch white and black films' is grammatically possible, psycholinguistically feasible, socioculturally appropriate, but 'white and black films' does not have the probability of occurrence as 'black and white films' does.

Hymes' idea of communicative competence focused on a first language and the communication between the speakers of the same language. Canale and Swain, in their model of communicative competence, emphasized second/foreign 
language learning and teaching. While Hymes underlined that "there are rules of use without which the rules of grammar would be useless" ("On Communicative Competence" 278), Canale and Swain pointed out that these two groups of rules are useless without one another (6). Their model of communicative competence to be applied to second language teaching and assessment is composed of grammatical, sociolinguistic, and strategic competencies. Grammatical competence covers the knowledge of grammar, lexicon, and phonology. Sociolinguistic competence, on the other hand, includes both rules of use (appropriateness) and discourse (register and style) because knowledge of these rules is "crucial in interpreting utterances for social meaning" (Canale and Swain 30). The third component, strategic competence, involves the verbal and nonverbal communication strategies used such as in taking turns or breakdowns. This communicative competence model still has huge implications in second/foreign language syllabus design, teaching methodology, teacher education and training, materials development, and language testing.

Communicative competence sets the native speaker model as the target of foreign language learning, and language learners are given as if the only aim to excel in a foreign language were to communicate with merely its native speakers. However, today's global world encourages people from different first languages to communicate with one another in a language (English) that is not native to any of them. This brings people from different cultures to interact in a common language and shows the need for another competence: intercultural communicative competence. ICC expands communicative competence and stresses not a native speaker model as the target but an intercultural speaker model, which reflects a much more relevant model for the needs of today's multicultural world. This competence involves the ability to understand one's own culture and other cultures, and to use this understanding to communicate with people coming from different national or local cultures. Byram's model of ICC ("Teaching and assessing intercultural communicative competence" 34) puts critical cultural awareness (of one's own culture and other cultures) at the center of education and requires language users to have certain attitudes (such as willingness, curiosity, interest, and openness towards different cultures or people to overcome prejudice and stereotypes), knowledge (of how different cultures or social groups communicate and interact within themselves and with others), and skills (interpreting documents or events from other cultures to explain them, and discovering knowledge through social interaction).

Foreign language teachers of today are responsible for creating a learning environment not only to develop and improve language skills but also to integrate intercultural communication and critical awareness, and skills such as cooperation, mediation, or negotiation into their classes. Byram ("Intercultural competence in foreign languages" 324) states "teachers intend to include cultural dimension but do so only intermittently and in unplanned ways... [due to] lack of attention to the cultural dimension in teacher training". Thus, it is highly important to address and integrate culture and ICC in pre-service foreign language teacher education programs because "intercultural citizenship encouraged by foreign language teachers goes further and promotes the 
formation of communities of action beyond the boundaries of the state/country" (Byram, "Intercultural competence in foreign languages" 327).

\section{Methodology}

Cushner and Mahon (304) state that developing young people's intercultural competence "requires a core of teachers and teacher educators who have not only attained this sensitivity and skill themselves but are also able to transmit this to the young people in their charge". Similarly, Wagner, Perugini, and Byram (x) maintain "additional guidance in the area of intercultural communicative competence may empower teachers to confidently design lessons in intercultural competence". Designing such lessons for young learners is much more essential as they are the future generation. Therefore, a teacher education session on teaching English to young learners (YLs) was planned to help teacher candidates become familiar with ICC as the "action" of this study. The research to follow this action aims to explore the answers to the following questions:

(1) How effective can a teacher education session be in achieving its goals based on the elements of ICC (attitudes, knowledge, skills, and awareness)?

(2) What do the teacher candidates think about integrating culture and ICC into foreign language teaching based on their experience in this training session?

Dörnyei (191) indicates that action research has a "close link between the research and teaching", and it is "conducted by or in cooperation with teachers to gain a better understanding of their educational environment and improve the effectiveness of their teaching". Similarly, the researcher of this study was also the teacher educator of the education environment where the study took place. Thus, the research intention was to make foreign language teacher education more effective and relevant for the needs of the teacher candidates who are the participants of the study.

Cohen et al. (226) share a list of areas where action research can be used. According to their list, the action in this study addresses attitudes and values, and aims to focus on "encouraging more positive attitudes to work or modifying pupils' value systems concerning some aspects of life". As the action is localized (to a group of students) and personal (decided by the teacher to improve practice), the researcher/teacher should plan, act, observe and reflect in the research process (Cohen et al. 234). Hence, the teacher educator (as the researcher) planned this action research study to examine how effective a teacher education session can be in achieving its ICC goals, and what teacher candidates think about integrating culture and ICC into foreign language teaching based on their experience in this training session. To explore this, a training session was designed and executed in a language teaching methodology course (Teaching English to Young Learners) specifically designed for preparing teacher candidates to teach English to young learners. During this session, the teacher educator/researcher took notes and audio recorded the group work activities and analyzed teacher candidates' reflection papers after the session. 
The present action research selects a Teaching English to Young Learners (TEYL) course offered in a foreign language education department (FLE) at a prestigious public university in Turkey as its context. TEYL is a must course in all undergraduate English language teacher education programs in Turkey. In 1997, the Turkish education system went through a large-scale reform, and compulsory education was extended to eight years from five, which led foreign language education to start in the fourth year of primary school education in public schools (Foreign language education in private schools starts in the first grade or kindergarten). Following this reform, the teacher education programs were redesigned, and a new curriculum was put into effect starting from the 1998-99 academic year by the Council of Higher Education. With this reform, the number of methodology courses was increased, and TEYL was one of the courses added as a must course in undergraduate teacher education programs and offered for the first time in the 2000-2001 academic year. The course continued to be offered after the changes (known as $4+4+4$ ) in the system of national education in 2012, and in the undergraduate teacher education curricula in 2018.

TEYL offered in the research context aims to introduce third-year studentteachers with the concept of teaching English to YLs, activities and instructional techniques specifically designed for and used with children, and concepts of classroom management, materials design, and assessment. Over the years, the course content was modified according to a need analysis conducted among program graduates and practicum mentors (Şallı-Çopur in her presentation), instructor's personal experience with YLs and teachers of young learners, changes in the English language teaching in national education, recent publications in the field, and cooperation with teacher educators in national and international institutions (Please see Appendix A for the course outline used by the teacher educator/researcher). The sequencing of the course content represents, what Posner and Rudnitsky (153) called, a 'blend' of a combination of three principles: general to specific, chronology (topics on teaching language elements and skills follow a chronological order which reflects children's reallife encounter with them), and parts to the whole. Course methodology involves active learning techniques including class discussions, pair/group work activities on tasks, and discussions on real (anecdotal) cases. The assessment procedures include class discussions in groups, activity presentations in pairs/triads, individual written reflections, and a final exam. The course has three contact hours each week with no practicum component.

The course session on ICC was designed to be implemented almost in the middle of the term with a practical training session in the form of a demo lesson, where student-teachers participate as young learners studying in a 5th-grade young learner classroom (See Appendix B for the demo plan). This implementation reflects a teacher-initiated bottom-up approach to syllabus design because the need for such addition was not imposed by the CoHE nor was it emphasized by the institution. Neither the students nor the graduates of the program expressed their need either. Considering the demands of the global world and the realities of the national context (such as the high number of Syrian refugee children in 
Turkish public schools), the course instructor (the researcher) included ICC as an essential component of the course. White $(131,133)$ explains this implementation model as "localized in application emphasizing the definition and solution of problems which arise within individual institutions rather than across a complete system".

The participant teacher candidate group was sixty-five 3rd-year FLE students (in two sections). Their contribution in the groupworks (15 groups; $4-5$ teacher candidates in each group) during the demo and individual reflection papers written after class were used as the two qualitative data sets of this teacher educator-initiated research. Figure 1 shows the process followed to conduct the action research.

Figure 1 Process of the Action Research

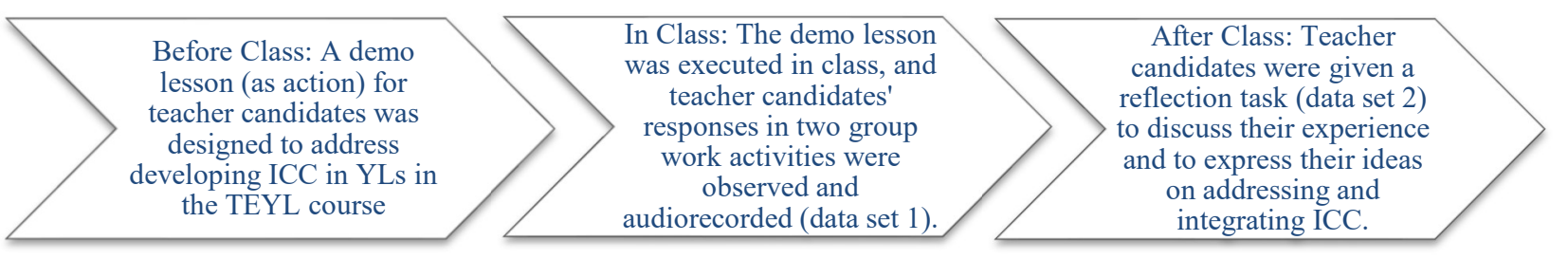

The demo lesson revolves around a "breakfast" theme. The participants are put into groups and given a picture of different breakfast plate/table. Each group identifies the food on the breakfast plate and predicts the country it belongs to. During the activity, the teacher educator/researcher asks groups to audio record their group exchanges, and she walks among the groups to see how they make predictions based on the given visuals and takes notes of them. This group work finishes when all breakfast plate pictures are shared one by one with the predictions, so that each group may have an idea about what the other groups have worked on. The countries whose breakfast plates were shared are (in alphabetical order): France, India, Israel, Japan, Mexico, Sweden, Syria, and United Kingdom. The participants are encouraged to focus on the similarities and differences after each breakfast plate is shown and its country is revealed. This activity is a preliminary activity for the main task of the demo. Following that, the groups are shuffled in a jigsaw principle. As the main task, the participants are presented a hypothetical situation: Children from different countries have been invited to Turkey for the April 23 National Sovereignty and Children's Day, and a Turkish family hosts a breakfast for a small group of children from five countries. The groups now prepare (draw) a breakfast table for this multicultural group of children keeping in mind the breakfast habits discussed in the preliminary activity based on the given pictures. The teacher educator/researcher asks groups to audio record their exchanges during this groupwork activity as well, and she also walks among the groups to take notes of group exchanges that shows their background knowledge, attitude, and negotiation skills. The lesson ends with putting the breakfast table drawings on the walls so that each group may see each other's work.

The demo is the instrument of the training session to reach the goal, which is to have teacher-candidates become aware of how to integrate culture and intercultural competence into language classes. As Cushner and Mahon (316) 
state, "Developing intercultural sensitivity and competence is not achieved in the cognitive-only approach to learning that is common in most classrooms today, be it with children or pre-service teachers. Culture learning develops only with attention to experience and the affective domain". That is why the demo lesson not only addresses cultural aspects teacher candidates may know about or heard of world cultures but also provides an opportunity for them to share about their local and national culture, which they are emotionally connected to and experience in everyday of their life.

Teacher educator's notes and audio recordings during the group work activities were used as the first data set of this study to examine how effective the session was to achieve the goals of knowledge, attitudes, and skills of interpretation or negotiation based on Byram's ICC model. After class, teacher candidates were given a reflection task on their demo experience, which stands as the second data source of this study. In their reflection paper, teacher candidates were expected to identify the goals of the lesson based on the ICC model, and their opinion on the integration of culture and ICC into foreign language classes. These two sets of qualitative data (data collected during the demo based on the groupworks, and after the demo based on reflection papers) were analyzed and samples were shared to demonstrate teacher candidates' experience and their opinions based on this experience.

\section{Findings}

The data collected during the training session (from teacher's notes and group work recordings) and after it (from participant reflections) were analyzed to answer the research questions. Byram and Masuhara (148) state that "all five elements [of Byram's ICC model] should be reflected in the objectives teachers use in planning their teaching". Thus, the first research question aims to explain how effective the teacher education session was in achieving its ICC goals based on these elements.

First, considering the attitudes element, the session aimed to create interest, curiosity, and openness among participants to learn more about other's cultures, customs, and practices, and to create awareness of similarities and differences within the local culture and between different cultures. The analysis of the data showed that there was no negative remark on any local, national, foreign, or global cultural element mentioned in the demo based on the breakfast habits. The observation notes demonstrated that teacher candidates in all groups focused on not only the differences from one culture to another while they were trying to find out which country the breakfast plates belong to but also the similarities between/among their (local) culture and other cultures. Participants' comments also showed that they were either surprised with the similarities between their culture and foreign culture, or highly eager to try different food of different cultures. To illustrate, more than half of the groups shared their surprise to see how the Syrian and the Israeli breakfast tables were similar to the Turkish breakfast in the first group activity. In addition, two groups were very much interested in the Japanese breakfast, and both started sharing their curiosity in tasting the food on the given picture and one group 
even used their mobile phones to check other visuals on Japanese food. Some other groups talked about the small portions in some breakfast plates such as French or Swedish breakfast. Their responses were not negative, but they were trying to understand, as one of them continued the discussion in his reflection saying that "in Europe most of the countries do not have heavy breakfast, they eat more in lunch and dinner". He also mentioned that he "became more curious about other nation's breakfast habits and watched some videos on YouTube". Although teacher candidates did not criticize any breakfast habit, the groups working on the Brazilian and Indian breakfast plates imagined themselves having those as children and questioned whether it would be a bit too much to eat in the morning.

Based on the second element, knowledge, of ICC, the training session aimed to develop knowledge of practices in one's own and in other cultures. It was seen in the data that the teacher candidates developed an understanding and knowledge of different breakfast habits in their own culture and other cultures while they worked in groups. Both the researcher's notes and the recordings showed that most groups discussed how to cook menemen, mihlama, or kuymak (the traditional Turkish local food), and/or what type of Turkish pastry (pişi/bişi, simit, gözleme, ballk ekmek) could be tasty for people from cultures with different breakfast habits. Reflections after class also gave details about how teacher candidates developed an understanding of the local practices in Turkey and some foreign cultures. One of them wrote that her groupmate had been to Spain to study a term through the Erasmus exchange program and talked about Spain's cultural breakfast habits. According to teacher notes, another one shared her experience with "porridge" when she was talking on the breakfast plate from the UK to talk about variations within the same country, and she explained it in detail for the ones who had never tasted it. This group even compared porridge to keşkek, which is popular in some parts of Turkey. Another piece of information learned during the group work was about olives, which are highly popular in Turkish breakfast culture. One participant wrote in his reflection "neither my groupmates nor I knew that in some EuropeanMediterranean countries, such as Spain and Greece, olives are not served in the breakfast while it is a common practice in Asian Mediterranean countries like Lebanon or Syria". Besides, it was seen that one student even gave information in her reflection about chopsticks used in different Asian countries: "I knew that Korean, Chinese and Japanese chopsticks were different. When I mentioned that in the class, some of us [groupmates] learned a piece of new information, and later, some of them said that the difference among chopsticks was intriguing". In addition to those, the teacher candidates also formed an understanding through similarities between cultures. These similarities in some cases were new and unbelievable for some of them. In the second group work activity, where the participants were preparing (drawing) a breakfast table for children coming from different countries, one of the teacher candidates made a remark based on a new piece of knowledge she has just learned: "I did not know that Jews and Muslims are similar in terms of not having pork" and explained that this information made her feel closer to Israelis. 
The goals addressing the third and fourth elements of ICC (skills of discovery and interaction, and skills of interpreting and relating) in the demo lesson were to give participants a chance to use new knowledge of different cultures and cultural practices when needed, and to give them a chance to practice negotiation not to cause any conflict among different cultures. Almost all groups used their stereotypes as a starting point to predict the breakfast plates in the first group task, but knowing the stereotypes was not enough in the second task because they worked to prepare (draw) a breakfast table for children from six different cultures. The task required participants not only to apply the knowledge they have discovered on breakfast habits to complete a task but also to practice negotiation not to cause any conflict among people from different cultures. As the task gives some hints about the breakfast habits of children who join the hypothetical breakfast, all groups were trying to prepare a table where none of the kids would feel offended and all kids would leave the table full according to the customs of the Turkish culture. To illustrate, one of the group participants was reminding her groupmates that "Israelis do not mix meat and dairy products" to convince them to prepare a vegetarian breakfast table, although sucuklu yumurta (scrambled eggs with sausage) was suggested. A similar case happened in another group where the participants decided to place both forks and chopsticks for each child, as they imagined "children may like to try chopsticks with the Japanese kid". Moreover, groups discussed serving both tea and coffee, and some groups thought serving water and orange juice only, as the guests are children. The groups even discussed how to place the food on the table saying that "cooked vegetables should be close to the British child". One teacher-candidate referred to how they negotiated in his reflection:

What we have learned with my group members from that activity was that even preparing a simple breakfast table by considering different cultural issues and preventing potential conflicts is not easy at all. On the one hand we wanted to satisfy Indian guest's needs by not serving sucuk [sausage] which is a good example of traditional Turkish food, on the other hand we really wanted to show Turkish hospitality by serving as much food as we can.

The last, and the core, ICC element addressed was critical cultural awareness, with two goals: to help participants to be aware of possible situations/problems, and to help them become aware of their stereotypes (if any) to overcome them. Throughout the second group task, the groups were trying to solve hypothetical problems that may appear and overcome their own bias. When they were preparing (drawing) the breakfast table in the Turkish house, they wanted to add food representing the Turkish culture, but it was not easy for them to agree on which food represents the national culture better than the others, and each started sharing their breakfast habits in their hometowns and realized how difficult it is to have a standard representation of cultures. One teacher candidate mentioned in his reflection, having a critical look at his eating habits, that his best friends (also study participants) and he talked about the training session after class and realized they use their negotiation skills all the time when they eat together as one of them is a vegan. Moreover, the critical look at national 
or personal cultures went beyond the breakfast tables and moved to international relations. One of the teacher candidates mentioned after the demo that he would love to design such activities in class, but he had reservations about including certain cultures in class not to cause any conflicts, as he was worried about parents' reactions: "I think we should include all cultures, but the parents may tell me they do not want their kid to learn about this culture or that culture". This response shows teachers not only need to overcome their or their students' negative stereotypes, but they also must face those of the parents.

After class, 55 of the 65 teacher candidates submitted a reflection paragraph/ essay. These papers were on what teacher candidates think about integrating culture and ICC into foreign language teaching after their training experience. The analysis of the reflections highlighted three main themes in teacher candidates' ideas: the importance of teaching culture in language classes, the role of culture teaching in changing people's attitudes positively, and the timing of teaching culture in language teaching.

More than half of the teacher candidates $(\mathrm{N}=34)$ based their reflection on the importance of teaching culture in foreign language classes, and all these responses were in favour of language-culture integration. The discussion based on this theme revolved around two aspects: vocabulary and comprehension. Most of the 34 responses referred to how language and culture are intertwined and how language represents traditions and customs referring to vocabulary items, idioms, proverbs to show that these are culture-bound, and cannot be fully grasped without cultural information. One teacher candidate explained her ideas as: "in order to make sense of some phrases or basically evoke some interest, we need to teach the language through the culture of that country. Otherwise, it will look like a rote-memorization and translation of a language into another". The other point for the integration of culture into language teaching was its impact on comprehending written or spoken authentic texts. To illustrate, one of them explained how culture teaching should be designed while teaching languages referring to literary works produced in that language:

We cannot separate language from culture. Language teaching requires authentic materials which contains cultural elements. (...) If we want to teach a language, we must teach some literary works from the target culture as well... Without culture, language [teaching/learning] is not different from Maths.

Fourteen reflections focused on how integrating culture into education may change people's attitudes from negative to positive such as making them tolerant, flexible, and understanding. One teacher candidate explained this change referring to respect: "People are afraid of whatever they do not know. Culture is not an exception. We should bear in our minds that learning a language is a great way to understand and respect others who are different from you". He also underlined that integrating culture into education may eliminate negative stereotypes, discrimination, and even xenophobia. Another participant referred to integrating intercultural competence into education to change intolerance among people saying: "the world feeds off on intolerance. Through 
education, we can aim to break these patterns of intolerance and promote intercultural skills". One other teacher-candidate talked about the responsibility teachers have for developing empathy in young people:

We see tremendous hate towards different cultures, religions, and races. We see hate murders every day. I think as teachers, we should make our students show empathy about differences in our world. If they know there are millions of children that have different races, religions and cultures around the world that share same feelings for love, happiness, and sadness, they can understand that differences should be embraced.

Different from the others, one reflection paper was on the first-hand experience of a teacher candidate after starting university and being aware of different cultures. He stated, "I believe in the beauty of differences," and shared how he learned how to communicate with university students from different parts of the country:

People from small cities live in a culture where differences are not tolerated well. A couple of years ago I was one of them. After coming here [university], I realized that we as human beings have an endless variety of physical and mental features. I found out the outer space only after reading philosophers and authors from all around the world and meeting people from different backgrounds. When I look back, I see a person who was not able to be an individual. And only the individuals can tolerate differences. ... This can be achieved only by knowing one another.

Eight reflections touched on the timing of teaching culture referring to the proficiency level of learners. Seven of these were in favour of starting culture teaching explicitly or implicitly with young learners, although their proficiency level is not very high. One of them supported this referring to a positive change: "It is actually better to expose students at the early stages to different cultures so that they become more tolerant and more understanding of others". Another one said "the earlier the better" referring to her experience of learning Italian in terms of integrating culture to language teaching: "You can't expect students to love a language when you teach grammar and show them only the technical stuff. When you show your students the culture behind that language, it gives them a chance to relate and connect". Although the timing of culture teaching appeared as a different theme in the data analysis, all these responses either referred to the importance of language-culture integration or to the positive changes that may cause through ICC integration.

\section{Discussion, Implications and Conclusion}

Although the teacher education session planned as the "action" of this research study was successful in achieving its goals based on the elements of ICC (attitudes, knowledge, skills, and awareness), this can never be enough to ensure that teacher candidates become interculturally competent or develop a full understanding of ICC to integrate it into their teaching. As a matter of fact, the teacher educator as the action researcher of this study did not intend to 
design "the action" to create an instant change. On the contrary, she believes the action research is not an end but a beginning. Fantini ('Teaching ESOL as Intercultural Competence') says "whereas knowledge can be forgotten, awareness is irreversible". With the same premise, the main aim of the demo session presented as "action" was to raise teacher candidates' awareness both as foreign language teacher candidates and as intercultural citizens. As teacher candidates, the participants not only showed signs of interest and curiosity during/after the demo but also indicated a need to integrate cultural aspects and address ICC in foreign language teaching. As intercultural citizens, some teacher candidates developed new knowledge about and/or perspectives towards different local or foreign cultures after participating in a teacher education session. Wagner et al. (8) maintain "language teaching should encourage learners to challenge the accepted, the taken-for-granted norms and practices of dominant culture in their own country and in others". In a world that is getting larger in population and more connected in communication, addressing local and global cultures and developing ICC through formal education should not be seen as a preference but a necessity for education. To educate intercultural citizens, it is a prerequisite for teachers to be intercultural citizens, to show critical awareness, and to develop ICC. Thus, intercultural citizenship should be the aim of both K-12 education and teacher education.

\section{Works Cited}

Byram, Michael. Teaching and Assessing Intercultural Communicative Competence. Multilingual Matters, 1997.

Byram, Michael. "Intercultural Competence in Foreign Languages: The Intercultural Speaker and the Pedagogy of Foreign Language Education." The SAGE Handbook of Intercultural Competence, edited by Darla K. Deardorff, Sage Publications, 2009, pp. 321-332.

Byram, Michael and Hitomi Masuhara. "Intercultural competence." Applied Linguistics and Materials Development, edited by Brian Tomlinson, Bloomsbury, 2013, pp. 143-160.

Canale, Michael and Merrill Swain. "Theoretical Bases of Communicative Approaches to Second Language Teaching and Testing." Applied Linguistics, vol.1, no.1, 1980, pp. 1-47.

Chomsky, Noam. Aspects of the Theory of Syntax. Cambridge, MIT Press, 1965.

Cohen, Louis, et al. Research Methods in Education. 5th ed., Routledge Falmer, 2000.

Cushner, Kenneth and Jennifer Mahon. "Intercultural Competence in Teacher Education: Developing the Intercultural Competence of Educators and their Students." The SAGE Handbook of Intercultural Competence, edited by Darla K. Deardorff, Sage Publications, 2009, pp. 304-320.

Dörnyei, Zoltan. Research Methods in Applied Linguistics. Oxford University Press, 2007. Fantini, Alvino E. "Teaching ESOL as Intercultural Competence." TESOL Intercom, ICIS Newsletter. 6 March 2012, http://newsmanager.commpartners.com/tesolicis/issues/2012-03-06/1.html

Güneș, Gökalp and Enisa Mede. "Integration of Intercultural Communicative Competence (ICC) in an EFL Course: Perceptions of Students and Teachers." 
Inönü University Journal of the Faculty of Education, vol. 20, no. 2, 2019, pp. 352363.

Hymes, Dell. "Competence and Performance in Linguistic Theory." Language Acquisition: Model and Methods, edited by Renisa Huxley and E. Ingram, Academic Press, 1971, pp. 3-28.

Hymes, Dell. "On Communicative Competence." Sociolinguistics. Selected Readings, edited by John B. Pride and Janet Holmes, Penguin, 1972, pp. 269-293.

Posner, George J., and Alan N. Rudnitsky. Course Design: A Guide to Curriculum Development for Teachers. 7th ed., Pearson Education Inc., 2006.

Şallı-Çopur, Deniz. "A Quest to Improve the Undergraduate TEYL Course: A Case Study." IATEFL TTEd SIG Conference Projecting onto Teaching Young Learners, 20-21 September 2013. Muğla Sitkı Koçman University, Turkey.

UNESCO Preparatory Commission. Conference for the Establishment of the United Nations Educational, Scientific and Cultural Organisation. 1-16 November 1945. Fifth Plenary Meeting, Document Code ECO/CONF/29, 1946, https://unesdoc.unesco.org/ark:/48223/pf0000117626. Accessed 3 May 2021.

Wagner, Manuela., et al. Teaching intercultural Competence Across the Age Range: From Theory to Practice. Multilingual Matters, 2018.

White, Ronald V. The ELT Curriculum: Design, Innovation and Management. Basil Blackwell, 1988. 


\section{Appendix A: TEYL Course Outline}

\begin{tabular}{|c|c|}
\hline Course Objectives & Learning Outcomes \\
\hline $\begin{array}{l}\text { At the end of this course, } \\
\text { students will ... }\end{array}$ & By the end of this course the students will be able to ... \\
\hline $\begin{array}{l}\text { - be aware of the theoretical } \\
\text { and practical aspects of } \\
\text { teaching English to young } \\
\text { learners }\end{array}$ & $\begin{array}{l}\text { - discuss the differences between learning and acquisition } \\
\text { and its implications for language teaching. } \\
\text { - discuss the importance of input and exposure in language } \\
\text { learning. } \\
\text { - refute the misassumptions of child language learning } \\
\text { referring to research findings in the field. } \\
\text { - discuss the educational innovations on EFL teaching to } \\
\text { young learners in the local and national context }\end{array}$ \\
\hline $\begin{array}{l}\text { - know the difference } \\
\text { between young learners } \\
\text { and other age groups, and } \\
\text { among different young } \\
\text { learner groups. }\end{array}$ & $\begin{array}{l}\text { - distinguish among young learners and teenagers and } \\
\text { adults in terms of their attitude towards learning and } \\
\text { language learning, their language needs and language } \\
\text { learning aim, and language development. } \\
\text { - distinguish among different young learner age groups in } \\
\text { terms of their cognitive, affective psychomotor and moral } \\
\text { development }\end{array}$ \\
\hline $\begin{array}{l}\text { - know the theories of child } \\
\text { learning, child language } \\
\text { learning and children's } \\
\text { learning styles and } \\
\text { strategies }\end{array}$ & $\begin{array}{l}\text { - comprehend basic theories of child learning, child } \\
\text { language learning and different learning styles and } \\
\text { strategies. } \\
\text { - compare different theories of child learning, child } \\
\text { language learning and learning styles. } \\
\text { - discuss the theories of child learning, child language } \\
\text { learning in terms of foreign language learning of young } \\
\text { learners }\end{array}$ \\
\hline $\begin{array}{l}\text { - learn a variety of teaching- } \\
\text { learning activities, } \\
\text { materials, syllabus types } \\
\text { and assessment methods } \\
\text { for young learners }\end{array}$ & $\begin{array}{l}\text { - discuss a variety of activities to teach and practice } \\
\text { language elements (grammar, vocabulary, pronunciation) } \\
\text { and language skills (listening, speaking, reading, writing) } \\
\text { - analyze syllabus types designed for primary school } \\
\text { learning and discuss their relevance to the EFL } \\
\text { curriculum \& the learners. } \\
\text { - recognize that there are several options in dealing with } \\
\text { mistakes and assessment of learning in young learner } \\
\text { classes }\end{array}$ \\
\hline $\begin{array}{l}\text { - use instructional } \\
\text { techniques relevant for } \\
\text { different young learner } \\
\text { groups. }\end{array}$ & $\begin{array}{l}\text { - design motivating activities to promote effective learning } \\
\text { in young learners } \\
\text { - integrate a variety of instructional techniques such as } \\
\text { games, songs, stories, visuals etc. to support young } \\
\text { learners' language learning in class } \\
\text { - develop the confidence to become creative, flexible, and } \\
\text { adaptable in all classroom conditions and situations. }\end{array}$ \\
\hline $\begin{array}{l}\text { - become familiar with the } \\
\text { classroom management } \\
\text { methods and techniques to } \\
\text { be used when teaching } \\
\text { English to young learners }\end{array}$ & $\begin{array}{l}\text { - list a few classroom management options to manage } \\
\text { students, time, and the physical environment. } \\
\text { - discuss appropriate classroom configurations, student } \\
\text { interaction patterns, optimal uses of time, mistake } \\
\text { management, and assessment of learning }\end{array}$ \\
\hline
\end{tabular}


Week 1 Characteristics of young learners

Differences among young learners, teenagers, and adults

Differences between very young and older young learners

Week 2 Theories on child learning

Myths and facts about young learners

Week 3 Learning styles and mixed ability

Learning difficulties and disability

Communicating with parents

Week 4 Teaching vocabulary to young learners

Week 5 Teaching listening and speaking to young learners

Week 6 Teaching reading and writing to young learners

Week 7 Teaching grammar to young learners

Week 8 Culture in YL Classes and Intercultural Communicative Competence

Week 9 Instructional techniques for young learners

Stories, songs, games

Technology and multimedia

Week 10 Classroom management with young learners

Communicating with students

Organizing class activities: interaction patterns

Motivation and discipline problems

Week 11 Classroom management with young learners (continued)

In-class panel with guest speakers

Week 12 Syllabi and materials for young learners

Week 13 Assessment techniques for young learners

Error correction

Alternative techniques

Week 14 Teaching young learners in Turkish school context

Reforms and innovations

\section{Grading}

Activity Presentation (pairs/triads): $\quad 15 \%$

Poster Design \& Presentation (pairs/triads) 20\%

Discussion \& Reflection Tasks $\quad 40 \%$

Final Exam 20\%

Participation (in Class Discussions \& Activities) $\quad 5 \%$ 
Appendix B: Lesson Plan for TEYL Class on ICC

\begin{tabular}{|c|c|c|}
\hline Time & Procedure & Rationale \\
\hline $2^{\prime}$ & $\begin{array}{l}\text { Teacher invites the class to the board to } \\
\text { sing the song of the day. They sing the } \\
\text { new song (Peanut Butter and Jelly) with } \\
\text { the teacher. } \\
\text { The students may be introduced "peanut } \\
\text { butter" and "jelly" as the food to have in } \\
\text { American breakfast. }\end{array}$ & $\begin{array}{l}\text { Every week this student teacher group } \\
\text { learns a song to be used with young } \\
\text { learners. These songs also show the } \\
\text { importance of routines in young } \\
\text { learner classrooms. } \\
\text { Breakfast is a part of each culture. } \\
\text { With the movies, TV series, stories, } \\
\text { and coursebooks, students are familiar } \\
\text { with the breakfast types in the } \\
\text { Western world. This part stands as an } \\
\text { intro to the topic of week: What to eat } \\
\text { in breakfast in different cultures. }\end{array}$ \\
\hline $3^{\prime}$ & $\begin{array}{l}\text { After the song, the teacher makes a table } \\
\text { on the board in } 2 \text { columns: One column } \\
\text { for the American culture and one for the } \\
\text { home culture (Turkish). She puts peanut } \\
\text { butter and jelly into the first column and } \\
\text { writes what she had for breakfast that } \\
\text { day for the second column (Simit, } \\
\text { cheese, and tea). She asks students to } \\
\text { write as many items as possible for any } \\
\text { column they like. }\end{array}$ & $\begin{array}{l}\text { This part is to help students become } \\
\text { aware of what they know about the } \\
\text { breakfast habits of an English- } \\
\text { speaking country and their own } \\
\text { culture. }\end{array}$ \\
\hline $10^{\prime}$ & $\begin{array}{l}\text { The teacher puts the students in groups } \\
\text { of } 5 \text {, gives each group a picture of a } \\
\text { breakfast plate from a different culture } \\
\text { and asks them to identify the food in } \\
\text { those pictures and predict the country } \\
\text { where the picture is from. The groups } \\
\text { should justify their choices. (The teacher } \\
\text { may also provide the names of the food } \\
\text { on those plates to help the groups } \\
\text { describe their picture). After that, } \\
\text { teacher shows the pictures on the PPT, } \\
\text { and each group talk about the breakfast } \\
\text { plate they have and share their } \\
\text { predictions. }\end{array}$ & $\begin{array}{l}\text { The students recycle and learn food } \\
\text { related vocabulary items. They also } \\
\text { become familiar with different } \\
\text { breakfast habits of different countries. }\end{array}$ \\
\hline $15^{\prime}$ & $\begin{array}{l}\text { After the students share their plates, } \\
\text { teacher gives each group a list of young } \\
\text { guests from different countries coming } \\
\text { to Turkey for "April 23rd National } \\
\text { Sovereignty and Children's Day". Each } \\
\text { child is coming from a different culture } \\
\text { and has different breakfast and eating } \\
\text { habits. The groups should prepare a } \\
\text { breakfast table for these guests. The } \\
\text { table should be appealing to all young } \\
\text { guests and should not be offending for } \\
\text { anyone. }\end{array}$ & $\begin{array}{l}\text { The students should work in groups to } \\
\text { prepare something for an intercultural } \\
\text { context, which stands as a model of } \\
\text { keeping in mind different cultures and } \\
\text { personal choices and habits. }\end{array}$ \\
\hline
\end{tabular}




\begin{tabular}{|c|c|c|}
\hline $5^{\prime}$ & $\begin{array}{l}\text { They share their work on the walls so } \\
\text { that each group may see what the others } \\
\text { prepare for an international breakfast. }\end{array}$ & $\begin{array}{l}\text { The groups may evaluate each other's } \\
\text { work }\end{array}$ \\
\hline & $\begin{array}{l}\text { Homework: Each group may have an } \\
\text { internet search on why a certain type of } \\
\text { food is preferred in certain cultures. }\end{array}$ & \\
\hline \multicolumn{3}{|c|}{$\begin{array}{l}\text { Attitudes: } \\
\quad \text { - to create interest, curiosity, and openness among participants to learr }\end{array}$} \\
\hline \multicolumn{3}{|c|}{$\begin{array}{l}\text { - to give participants a chance to use new knowledge of different cultures and cultural } \\
\text { practices when needed. }\end{array}$} \\
\hline \multicolumn{3}{|c|}{$\begin{array}{l}\text { - to give participants a chance to practice mediation not to cause any conflict among } \\
\text { different cultures. }\end{array}$} \\
\hline \multicolumn{3}{|c|}{$\begin{array}{l}\text { - to help participants to be aware of possible situations and problems. } \\
\text { - to help participants become aware of their stereotypes (if any) to overcome them. }\end{array}$} \\
\hline \multicolumn{3}{|c|}{ Food Info to be given to students during prediction activity in groups } \\
\hline & $\begin{array}{l}\text { cheese (string cheese \& mozzarella), } \\
\text { olives, eggs, dried meat, vegetables, } \\
\text { humus, pastry with spice and mint, } \\
\text { olive oil, halva...etc. }\end{array}$ & $\begin{array}{l}\text { 2. steamed rice, fish, seaweed, } \\
\text { vegetables, miso soup (soybeans), } \\
\text { corn bread }\end{array}$ \\
\hline & $\begin{array}{l}\text { chips, salsa, red and green pepper, } \\
\text { onions, potato, egg, crème }\end{array}$ & $\begin{array}{l}\text { 4. spicy dip } \\
\text { like tort }\end{array}$ \\
\hline & $\begin{array}{l}\text { open-face sandwich wi } \\
\text { cheese, mayonnaise, an } \\
\text { like cucumber and tom }\end{array}$ & $\begin{array}{l}\text { 6. eggs, sausage, bacon, beans, cooked } \\
\text { tomato }\end{array}$ \\
\hline & $\begin{array}{l}\text { vegetables, fruits, pastry, eggs, } \\
\text { humus, spicy dips, olives }\end{array}$ & 8. coffee \& croissant \\
\hline \multicolumn{3}{|c|}{$\begin{array}{l}\text { Group Task: Preparing a breakfast table for } \\
5 \text { ten-year old children coming for breakfast to a Turkish house: } \\
\text { An Israeli, an Indian, a Japanese, a Mexican and a Brit } \\
\text { - } \quad \text { Most Turks do not have seafood at breakfast. } \\
\text { - } \quad \text { Most Israelis do not eat pork and they do not mix meat and dairy products in the } \\
\text { same meal. } \\
\text { - } \quad \text { Some Indians do not eat beef. } \\
\text { - } \quad \text { Some Japanese prefer to eat with chop sticks. } \\
\text { - } \quad \text { Mexicans may prefer to have coffee. } \\
\text { - } \quad \text { Brits prefer to have fried vegetables and toasts. }\end{array}$} \\
\hline
\end{tabular}

